\title{
Potential influence of plant chemicals on infectivity of Batrachochytrium dendrobatidis
}

\author{
Elizabeth W. Davidson*, Andrew Larsen, Crystal Meins Palmer
}

School of Life Sciences, Arizona State University, Tempe, Arizona 85287-4501, USA

\begin{abstract}
We explored whether extracts of trees frequently found associated with amphibian habitats in Australia and Arizona, USA, may be inhibitory to the fungal pathogen Batrachochytrium dendrobatidis $(B d)$, which has been associated with global amphibian declines. We used salamanders Ambystoma tigrinum as the model system. Salamanders acquired significantly lower loads of $B d$ when exposed on leaves and extracts from the river red gum Eucalyptus camaldulensis, and loads were also low in some animals exposed on extracts of 2 oak species, Quercus emoryi and $Q$. turbinella. Some previously infected salamanders had their pathogen loads reduced, and some were fully cured, by placing them in leaf extracts, although some animals also self cured when housed in water alone. A significant number of animals cured of $B d$ infections 6 mo earlier were found to be resistant to reinfection. These results suggest that plants associated with amphibian habitats should be taken into consideration when explaining the prevalence of $B d$ in these habitats and that some amphibians may acquire resistance to the fungus if previously cured.
\end{abstract}

KEY WORDS: Batrachochytrium dendrobatidis - Ambystoma tigrinum - Eucalyptus - Quercus · Oak · Inhibition

Resale or republication not permitted without written consent of the publisher

\section{INTRODUCTION}

The fungal pathogen Batrachochytrium dendrobatidis $(B d)$ has been associated with amphibian declines worldwide (Collins \& Crump 2009, Lötters et al. 2009, Collins 2010, Kilpatrick et al. 2010). This fungus has been observed on amphibians in many habitats, but significant differences in prevalence have been reported among sites (e.g. McDonald \& Alford 1999, Woodhams \& Alford 2005, Peterson et al. 2007, Van Sluys \& Hero 2009, Kriger \& Hero 2008, Hossack et al. 2010, Murray et al. 2010, 2011, Skerratt et al. 2010). Many possible causes have been explored to explain this variation, including humidity, temperature, climate and seasonality (Bradley et al. 2002, Schlaepfer et al. 2007, Daskin et al. 2011, Murphy et al. 2011, Rohr et al. 2011, Rollins-Smith et al. 2011, Savage et al. 2011), skin peptides (Rollins-Smith et al. 2002, 2011, Rollins-
Smith \& Conlon 2005, Woodhams et al. 2006), chemicals (Lane \& Burgin 2008, Threlfall et al. 2008, Boisvert \& Davidson 2011), microbial flora (Harris et al. 2006, Brucker et al. 2008a,b, Becker \& Harris 2010), host genetics (Savage \& Zamudio 2011), species richness (Searle et al. 2011), environmental refuges (Puschendorf et al. 2011) and potential intermediate hosts (Daszak et al. 2004, Schloegel et al. 2010, Johnson et al. 2011, Kilburn et al. 2011, Gahl et al. 2012). However, one ecological factor that has not been widely explored is the potential influence of plants and plant chemicals in the habitats. Plant chemicals including phenols, tannins and alkaloids have been shown to influence the susceptibility of herbivorous insects to viral, fungal and bacterial pathogens (Cory \& Hoover 2006). In this study we explore whether chemicals associated with tree species found around amphibian habitats could have an effect on the outcome of $B d$ infections. 
In Australia, Eucalyptus spp. are common in the dryer and upland regions but are not common in the Queensland tropical rainforest, where the greatest loss of amphibians has occurred (Bowman 2000). In Arizona, USA, several oak (Quercus) species occur at intermediate and higher altitudes and near amphibian habitats (Elmore 1976). Eucalyptus and oak both regularly shed large quantities of dead leaves, seeds, and bark (Brooker 2002), which may fall into water and leach anti-fungal chemicals into it. Eucalyptus spp. produce oils, phenols, tannins, flavinoids and other chemicals with antimicrobial effects against bacteria and fungi (e.g. Deans 2002, Konoshima \& Takasaki 2002, Ghalem \& Mohamed 2008, Ben Marzoug et al. 2010, Gilles et al. 2010). The Australian tea tree Melaleuca spp. also produces antifungal compounds (Terzi et al. 2007). Oak leaves contain several antimicrobial chemicals such as phenolics (e.g. Güllüce et al. 2004, Karioti et al. 2011). We explored whether extracts from leaves of naturally occurring plant species may influence $B d$ growth and infection rates in tiger salamanders Ambystoma tigrinum.

We first tested whether extracts of dead leaves, bark and seeds from various tree species could inhibit $B d$ growth in an in vitro bioassay. We then exposed tiger salamanders held in leaves and extracts or in water alone to Bd. Ambystoma tigrinum is highly susceptible to $B d$ but does not usually die from infection and may live for over a year with infection (Davidson et al. 2003). We observed salamander skin sloughs microscopically and used quantitative PCR (qPCR) analysis to determine the presence and quantity of $B d$ on the salamanders held in leaf versus control treatments. Because extracts of plants such as purple loosestrife Lythrum salicaria can have a strong negative effect on the development of tadpoles (Maerz et al. 2005), we monitored all salamanders for signs of distress or mortality during our study, whether exposed to $B d$ or not.

Because exposed salamanders were found to be significantly less susceptible to $B d$ while housed on certain leaf preparations, we placed heavily infected animals into leaf extracts to determine whether an infection could be reduced or cured.

\section{MATERIALS AND METHODS}

\section{In vitro experiments}

For initial exploration of leaf extract antifungal activity, dead leaves, seeds and bark were collected from 17 species of trees and shrubs native to Australia at the Boyce Thompson Arboretum, Superior, Arizona (with permission): Casuarina crista, C. cunninghamiana, Melaleuca lanceolata, M. stypheloides, Acacia aneura, A. jennerae, Eucalyptus gilli, E. camaldulensis, E. polyanthemos, E. diptera, E. salubris, E. loxophleba, E. sideroxylon, E. salmonophloia, E. microtheca, and E. socialis. For in vitro bioassays, ca. $15 \mathrm{~g}$ of leaves, bark and seeds were incubated with $225 \mathrm{ml}$ distilled water in glass jars for $2 \mathrm{wk}$ at $30^{\circ} \mathrm{C}$. $\mathrm{pH}$ was taken using a Corning $\mathrm{pH}$ meter 430. Samples from each species were centrifuged and filter sterilized using a Pall Acrodisc (0.2 $\mu \mathrm{m}$ membrane). Sterile extracts were assayed in sterile 96-well plates against ca. $10^{5} B d$ zoospores $\mathrm{ml}^{-1}$ (Pseudacris triseriata strain, counted using a Bright-Line hemacytometer; Reichert Scientific), which had been cultured in tryptone-gelatin hydrolysate-lactose medium (TGhL; Longcore et al. 1999), at a final dilution of $25 \%$ plant extract to $75 \%$ TGhL with zoospores. Control wells contained either $25 \%$ extract and $75 \%$ TGhL but no zoospores, or $25 \%$ sterile distilled water and $75 \%$ TGhL with zoospores. For a second assay we diluted the most active extracts in sterile distilled water to $5 \%$ and $2.5 \%$ final concentrations in the zoospore/TGhL mixture. $B d$ densities at Day 0 and Day 2 were recorded using a Titertek Multiscan Plate Reader at $492 \mathrm{~nm}$, and wells were also observed using an inverted microscope (Sheafor et al. 2008). Because plant extracts alone led to darkening of TGhL, which was detected by the Titertek monitor, readings for extracts with TGhL without zoospores present were subtracted from readings for extracts with zoospores.

Samples of oak (Quercus) extracts used in in vivo experiments were taken before salamanders were added to shoe boxes, filter sterilized and assayed using 96-well plates as described above.

\section{In vivo experiments, Eucalyptus camaldulensis}

Eucalyptus camaldulensis leaves (15 g) and bark $(10 \mathrm{~g})$ were incubated in $1 \mathrm{l}$ aged tap water for $3 \mathrm{wk}$ at $30^{\circ} \mathrm{C}$ in each of 20 individual plastic shoeboxes. After 3 wk, 1 laboratory-reared Ambystoma tigrinum metamorph salamander was added to each shoebox. Before being added to shoeboxes, each salamander (ca. $30 \mathrm{~g}$ ) was swabbed on its back and abdomen using sterile toothpicks to confirm absence of $B d$ using qPCR as described by Hyman \& Collins (2012). Ten salamanders housed in leaf extracts and 10 housed in water alone were treated twice, 2 wk 
apart, with $1 \mathrm{ml}$ zoospores (Pseudacris triseriata strain) in TGhL medium (ca. $10^{6} \mathrm{ml}^{-1}$ ). The 20 remaining salamanders (10 in leaf extracts and 10 in water alone) were treated with $1 \mathrm{ml}$ TGhL medium twice, 2 wk apart, to act as $B d$ exposure controls. Salamanders were fed crickets twice weekly. Two weeks after the second exposure, all salamanders were moved to clean water and $1 \mathrm{~d}$ later swabbed on the back and abdomen with sterile toothpicks. Samples were extracted from the toothpicks and $B d$ loads determined using qPCR (Boyle et al. 2004, Hyatt et al. 2007). Salamander sloughs were also observed microscopically for the presence of $B d$ (Davidson et al. 2003).

\section{In vivo experiments, Quercus spp.}

Dead leaves, bark and acorns were collected from scrub (shrub) oak Quercus turbinella and Emory oak Q. emoryi at sites on the Mogollon Rim, near Payson, Arizona. Approximately $20 \mathrm{~g}$ of leaves, bark and acorns were added to $1 \mathrm{l}$ of aged tap water in each shoe box and incubated at $30^{\circ} \mathrm{C}$ for $2 \mathrm{wk}$.

Salamander metamorphs were swabbed for qPCR as above and placed into boxes containing leaf extracts or water alone (8 per treatment). Four animals from each group were inoculated twice, 1 wk apart, with $1 \mathrm{ml} B d$ zoospores (ca. $10^{6} \mathrm{ml}^{-1}$ ) while the remaining 4 were inoculated with $1 \mathrm{ml}$ TGhL (controls). All animals were moved to clean water $20 \mathrm{~d}$ after initial treatment and $B d$ loads determined as above.

\section{Curing experiments}

To determine whether exposure to leaf extracts could cure $B d$ infections, $15 B d$-inoculated salamanders exhibiting heavy $B d$ loads (mean \pm SD load 2900 \pm 6116 zoospore genome equivalents, zsp GE) were swabbed for the presence of $B d$. Five of these animals were placed in shoeboxes containing Eucalyptus camaldulensis leaves and extract, 5 in boxes containing Quercus emoryi leaves and extract, and 5 in water alone. After $4 \mathrm{wk}$, all were transferred to clean water. One day after their transfer to water, sloughs were collected and each animal was swabbed for qPCR analysis of $B d$ infection intensity. $B d$ loads were determined as above. Non-parametric MannWhitney $U$-tests and Kruskal-Wallis tests were used to compare zoospore loads between treatments (JMP version 5.1.2, SAS).

\section{RESULTS}

\section{In vitro experiments}

Most Eucalyptus spp. extracts inhibited the growth of $\mathrm{Bd}$ (3 to $66 \%$ increase in density) as compared to extracts from other species, some of which enhanced growth (96 to $499 \%$ increase) and the water control (125\% increase) (Table 1). The pH of extracts ranged from 6.5 to 6.7 ; dissolved oxygen content was not determined.

In the presence of Eucalyptus extracts, zoospores almost immediately lost motility on Day 0, and no sporangia or live zoospores were observed by Day 2 (Table 1). The most active extracts were from river red gum Eucalyptus camaldulensis, which inhibited $B d$ growth at concentrations as low as $2.5 \%$ extract (Table 2). Although Casuarina cunninghami extract appeared inhibitory in the first assay, it did not inhibit growth in the second assay. Further research then focused on E. camaldulensis.

Quercus turbinella and $Q$. emoryi extracts also inhibited motility and growth of $B d$ as compared to the water control (Table 3).

Table 1. Batrachochytrium dendrobatidis $(B d)$. Effect of Australian plant extracts on growth of $B d$ measured in vitro on Day 2 after exposure. Density change was determined between Day 0 and Day 2 and adjusted for density change in the negative control, i.e. extract and tryptone-gelatin hydrolysate-lactose medium (TGhL) with no zoospores present. Final dilution of extracts was $25 \%$ extract, $75 \%$ TGhL and zoospores. NG: no growth, dead zoospores; SPO: sporangia and live zoospores present

\begin{tabular}{|lcc|}
\hline Species & $\begin{array}{c}\text { Microscope } \\
\text { observation }\end{array}$ & $\begin{array}{c}\text { Density } \\
\text { change (\%) }\end{array}$ \\
\hline Eucalyptus gylli & NG & 3 \\
E. camaldulensis & NG & 8 \\
E. polyanthemos & NG & 10 \\
E. diptera & NG & 7 \\
E. salubris & NG & 2 \\
E. loxophleba & NG & 9 \\
E. sideroxylon & NG & 8 \\
E. salmonopholia & NG & 16 \\
E. microtheca & NG & 16 \\
E. socialis & NG & 38 \\
E. yilgarniensis & NG & 66 \\
Casuarina cunninghami & SPO & 5 \\
C. crista & SPO & 96 \\
Melaleuca lanceolata & SPO & 315 \\
M. stypheloides & SPO & 287 \\
Acacia aneura & SPO & 499 \\
A. jennerae & SPO & 396 \\
Water control & SPO & 125 \\
\hline
\end{tabular}


Table 2. Batrachochytrium dendrobatidis $(B d)$. Effect of dilution of plant extracts on $B d$ growth determined in vitro on Day 2 after exposure. $75 \%$ tryptone-gelatin hydrolysatelactose medium (TGhL) and zoospores was used for both extract dilutions, but the \% sterile distilled water was $20 \%$ for the $5 \%$ extract and $22.5 \%$ for the $2.5 \%$ extract

\begin{tabular}{|lcc|}
\hline \multirow{2}{*}{ Species } & \multicolumn{2}{c|}{ Density change (\%) } \\
& 5\% extract & 2.5\% extract \\
\hline Eucalyptus camaldulensis & 0 & 0 \\
E. sideroxylon & 25 & 5 \\
E. microtheca & 12 & 8 \\
Casuarina cunninghami & 59 & 64 \\
C. crista & 55 & 56 \\
Water control & 38 & 38 \\
\hline
\end{tabular}

\section{In vivo experiments, Eucalyptus camaldulensis}

Mean $( \pm \mathrm{SE})$ zoospore load for salamanders exposed to $B d$ in water alone $(\mathrm{n}=10)$ was $2259 \pm$ 830 zsp GE, while the mean zoospore load for those exposed while housed on Eucalyptus camaldulensis (n=10) was $170 \mathrm{zsp}$ GE $( \pm 64)$ (Mann-Whitney $U$-test, $\mathrm{df}=1, \mathrm{p}=0.011$ ) (Fig. 1a). One animal exposed while housed on $E$. camaldulensis was completely negative for $B d$ by qPCR. Sloughing of skin by animals exposed to $B d$ in water and by animals exposed on $E$. camaldulensis was dramatically different. Animals exposed in water alone produced many large dark sloughs with obvious $B d$ colonies, while animals exposed while housed on E. camaldulensis produced few, small, lighter sloughs with few or no microscopically visible $B d$ colonies. No $B d$ was detected on control animals, and no animals housed on E. camaldulensis extracts died or showed distress during the experiment.

\section{Quercus spp.}

Mean zoospore load for those exposed in presence of Quercus emoryi extracts $(\mathrm{n}=4)$ was $55.6 \pm$ 87.2 zsp GE and for those exposed in presence of Q. turbinella extracts $(\mathrm{n}=4)$ was $62 \pm 78 \mathrm{zsp} \mathrm{GE}$, while mean zoospore load for salamanders exposed to $B d$ in water alone ( $\mathrm{n}=4$ ) was $16237 \pm 25432 \mathrm{zsp}$ GE (Fig. 1b). However zoospore loads were not significantly different between treatments due to the small sample size (Kruskal-Wallis, $\mathrm{df}=2, \mathrm{p}=0.12$ ). No $B d$ was detected on control animals, and no animals housed on Quercus spp. extracts died or showed distress.
Table 3. Batrachochytrium dendrobatidis $(B d)$. Effect of Quercus spp. extracts on $B d$ growth determined in vitro on Day 2 after exposure. Density change determined between Day 0 and Day 2. Final dilution of extracts: $25 \%$ extract, $75 \%$ tryptone-gelatin hydrolysate-lactose medium (TGhL) and zoospores

\begin{tabular}{|lc|}
\hline Species & Density change (\%) \\
\hline Quercus turbinella & 30 \\
Q. emoryi & 21 \\
Water control & 123 \\
\hline
\end{tabular}

\section{Curing experiments}

Four of 5 salamanders previously infected with $\mathrm{Bd}$ housed in Eucalyptus camaldulensis extracts had their zoospore loads greatly reduced after $4 \mathrm{wk}$ (pretreatment mean load $2900 \pm 6116 \mathrm{zsp}$ GE; post-treatment mean load $288 \pm 644 \mathrm{zsp}$ GE). Four of 5 housed in Quercus emoryi extracts also had their zoospore loads reduced (pre-treatment mean load 1256 $\pm 2284 \mathrm{zsp} \mathrm{GE}_{\text {; }}$ post-treatment mean load $1132 \pm$ 2532 zsp GE). Three of 5 salamanders housed on $E$. camaldulensis extract and 4 of 5 housed on $Q$. emoryi extract had their zoospore loads reduced to 0 . Three of 5 animals housed in water alone were also fully

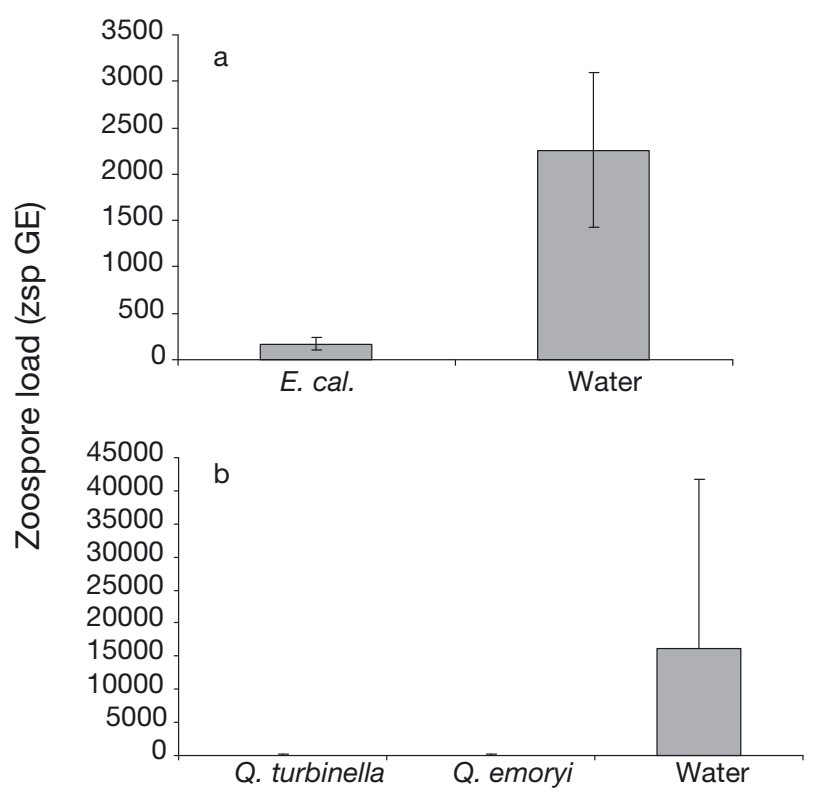

Fig. 1. Batrachochytrium dendrobatidis $(B d)$ infecting Ambystoma tigrinum. Mean $( \pm \mathrm{SE})$ zoospore loads of salamanders exposed to $B d$ when on (a) Eucalyptus camaldulensis (E. cal.) extracts $(\mathrm{n}=10)$ or (b) Quercus spp. extracts $(Q$. turbinella, $\mathrm{n}=4$, and $Q$. emoryi, $\mathrm{n}=4$ ). Extracts from both genera were compared to those in water $(\mathrm{n}=10$ and $\mathrm{n}=4$, respectively). zsp GE: zoospore genome equivalents 


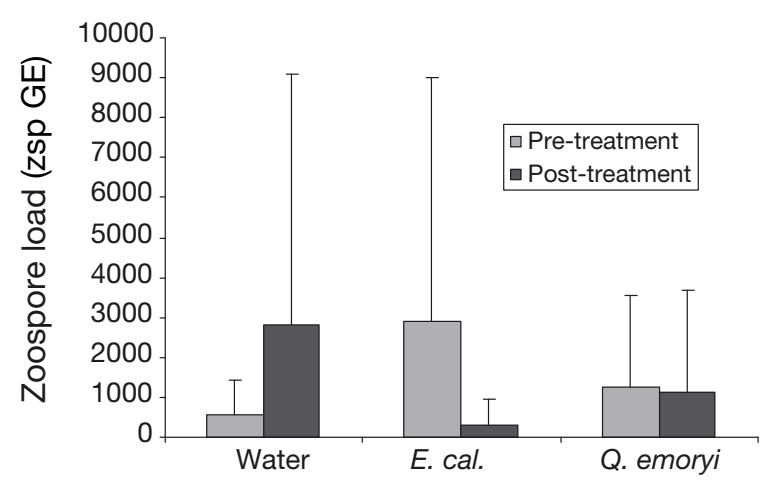

Fig. 2. Batrachochytrium dendrobatidis (Bd) infecting Ambystoma tigrinum. Mean $( \pm \mathrm{SE})$ zoospore loads of previously infected salamanders before and after being moved to water $(\mathrm{n}=5)$, Eucalyptus camaldulensis (E. cal.) $(\mathrm{n}=5)$ or Quercus emoryi $(\mathrm{n}=5)$ leaves and extracts for $30 \mathrm{~d}$. zsp GE: zoospore genomic equivalent

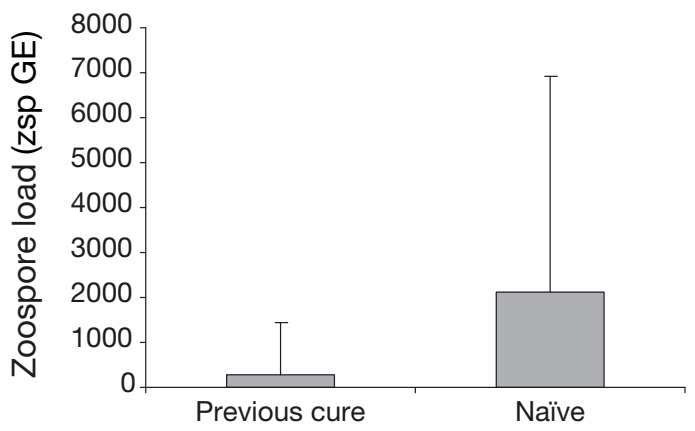

Fig. 3. Batrachochytrium dendrobatidis $(B d)$ infecting Ambystoma tigrinum. Mean $( \pm \mathrm{SE})$ zoospore loads in salamanders previously infected with $B d$ and cured by leaf extracts 6 mo earlier $(n=22)$ and in naïve animals $(n=8)$. zsp GE: zoospore genome equivalents

cured (pre-treatment mean $576 \pm 863 \mathrm{zsp}$ GE; posttreatment mean $2808 \pm 6276 \mathrm{zsp}$ GE) (Fig. 2). In each group, a single animal retained or increased its zoospore load, leading to the variation in the results; the number of animals losing infections was not significantly different between treatments.

When attempting to infect salamanders for the curing experiment, 22 Ambystoma tigrinum metamorphs that had been previously infected with $B d$ more than 6 mo earlier and cured by leaf extracts were treated twice with high concentrations of zoospores (ca. $10^{6} \mathrm{ml}^{-1}$ ). However the majority did not achieve high zoospore loads (mean $300 \pm 1135$ zsp GE) while 8 naïve metamorphs of the same age treated at the same time acquired significantly higher levels (mean $2132 \pm 4780$ zsp GE; KruskalWallis, df =1, p=0.0021) (Fig. 3).

\section{DISCUSSION}

Our results demonstrate that certain plant extracts in amphibian habitats may have an effect on the infectivity of $B d$. These results are based on extracts of the leaves of only a few species of trees, but they suggest that certain plants may influence $B d$ growth and infectivity. More work needs to be done to assess what the natural levels of leaf extracts are and how these concentrations can influence $B d$ dynamics. In contrast to our results, leaf litter and vegetation were found to be related to higher $B d$ infection in Pennsylvania newts Notophthalmus viridescens which was also related to cooler water temperature (Raffel et al. 2010). This demonstrates that in natural conditions the effect of plants may be more indirect by providing shade or thermal refugia for $B d$ growth. Becker \& Zamudio (2011) found that deforestation and habitat loss were negatively associated with the presence and intensity of $B d$ in Costa Rica and Australia and that disease was more common in undisturbed habitats. The tree species present in the studied habitats were not described in these studies, and as our in vitro studies demonstrated, activity of tree leaf extracts is highly species dependent, ranging from inhibition by some species to potential enhancement of growth by others. In addition to their presence in Australia, Eucalyptus camaldulensis and other species of Eucalyptus have been planted in Arizona and California, and species of Quercus are found throughout the USA, so chemicals from these trees may be found in many amphibian habitats. We do not yet know which of the many chemicals produced by Eucalyptus or Quercus (Deans 2002, Güllüce et al. 2004, Gilles et al. 2010, Karioti et al. 2011) are responsible for inhibition of $B d$ by the leaf extracts.

The ability of Ambystoma tigrinum previously cured of $B d$ infections to resist reinfection was unexpected. These animals had been free of infection for 6 mo or longer while housed in frequently changed water, and they regularly shed skin sloughs. Thus, it is unlikely that traces of plant extracts still remained in their skin. Not all animals appeared to acquire this resistance, but a large proportion of those we treated produced only low or no infection even after treatment with high levels of active zoospores. Resistance to $B d$ in previously cured Leiopelma archeyi frogs was reported by Shaw et al. (2010) and in toads Anaxyrus (Bufo) boreas by Murphy et al. (2011), suggesting that acquired resistance against this pathogen is possible, although an attempt to immunize Rana muscosa by injection of killed $B d$ culture was ineffective (Stice \& Briggs 2010). 
The ability of these extracts, in particular Eucalyptus camaldulensis, to reduce or eliminate infection in some $B d$-infected animals is encouraging. Recently Woodhams et al. (2012) have shown that many current techniques for treatment of amphibians were unsuccessful in eliminating $B d$ from infected frogs and tadpoles, and some were toxic. Since no salamanders died while housed in E. camaldulensis or Quercus extracts, our results suggest that extracts of these trees should be explored further against more sensitive species, in particular tadpoles, to determine if they may be a useful method for curing $B d$-infected amphibians.

Acknowledgements. We thank the Boyce Thompson Arboretum for permission to collect leaves; D. Jenke for collection and identification of plant samples; O. Hyman for manuscript review, PCR and statistical assistance; A. Zillmann for PCR and statistical assistance; and J. Collins and the ASU Ullman Fund for financial support.

\section{LITERATURE CITED}

Becker CG, Zamudio KR (2011) Tropical amphibian populations experience higher disease risk in natural habitats. Proc Natl Acad Sci USA 108:9893-9898

Becker MH, Harris RN (2010) Cutaneous bacteria of the redback salamander prevent morbidity associated with a lethal disease. PLoS ONE 5:e10957

Ben Marzoug HN, Bouajila J, Ennajar M, Lebrihi A and others (2010) Eucalyptus (gracilis, oleosa, salubris, and salmonophloia) essential oils: their chemical composition and antioxidant and antimicrobial activities. J Med Food 13:1005-1012

Boisvert SP, Davidson EW (2011) Growth of the amphibian pathogen, Batrachochytrium dendrobatidis, in response to chemical properties of the aquatic environment. J Wildl Dis 47:694-698

Bowman DMJS (2000) Australian rainforests: islands of green in a land of fire. Cambridge University Press, Cambridge

Boyle DG, Boyle DB, Olsen V, Morgan JAT, Hyatt AD (2004) Rapid quantitative detection of chytridiomycosis (Batrachochytrium dendrobatidis) in amphibian samples using real-time Taqman PCR assay. Dis Aquat Org 60:141-148

> Bradley GA, Rosen PC, Sredl MJ, Jones TR, Longcore JE (2002) Chytridiomycosis in native Arizona frogs. J Wildl Dis 38:206-212

Brooker I (2002) Botany of the eucalypts. In: Coppen JJW (ed) Eucalyptus, the genus Eucalyptus. Taylor \& Francis, London, p 3-35

Brucker RM, Baylor CM, Walters RL, Lauer A, Harris RN, Minbiole KPC (2008a) The identification of 2,4diacetylphloroglucinol as an antifungal metabolite produced by cutaneous bacteria of the salamander Plethodon cinereus. J Chem Ecol 34:39-43

Brucker RM, Harris RN, Schwantes CR, Gallaher TN, Flaherty DC, Lam BA, Minbiole KPC (2008b) Amphibian chemical defense: antifungal metabolites of the microsymbiont Janthinobacterium lividum on the salamander
Plethodon cinereus. J Chem Ecol 34:1422-1429

Collins JP (2010) Amphibian decline and extinction: What we know and what we need to learn. Dis Aquat Org 92:93-99

Collins JP, Crump ML (2009) Extinction in our times: global amphibian decline. Oxford University Press, New York, NY

> Cory JS, Hoover K (2006) Plant-mediated effects in insectpathogen interactions. Trends Ecol Evol 21:278-286

> Daskin JH, Alford RA, Puschendorf R (2011) Short-term exposure to warm microhabitats could explain amphibian persistence with Batrachochytrium dendrobatidis. PLoS ONE 6:e26215

Daszak P, Strieby A, Cunningham AA, Longcore JE, Brown CC, Porter D (2004) Experimental evidence that the bullfrog (Rana catesbeiana) is a potential carrier of chytridiomycosis, an emerging fungal disease of amphibians. Herpetol J 14:201-207

> Davidson EW, Parris M, Collins JP, Longcore JE, Pessier A, Brunner J (2003) Pathogenicity and transmission of chytridiomycosis in tiger salamanders (Ambystoma tigrinum). Copeia 2003:601-607

Deans SG (2002) Antimicrobial activity of eucalyptus oils. In: Coppen JJW (ed) Eucalyptus, the genus Eucalyptus. Taylor \& Francis, London, p 291-303

Elmore FH (1976) Shrubs and trees of the southwest uplands. Southwest Parks and Monuments Assoc, Tucson, AZ

> Gahl MK, Longcore JE, Houlahan JE (2012) Varying responses of northeastern North American amphibians to the chytrid pathogen Batrachochytrium dendrobatidis. Conserv Biol 26:135-141

Ghalem BR, Mohamed B (2008) Antibacterial activity of leaf essential oils of Eucalyptus globulus and Eucalyptus camaldulensis. Afr J Pharmacy Pharmacol 2:211-215

Gilles M, Zhao J, An M, Agboola S (2010) Chemical composition and antimicrobial properties of essential oils of three Australian Eucalyptus species. Food Chem 119:731-737

Güllüce M, Adigüzel A, Öğütçü $H$, Şengül M, Karaman I, Şahin F (2004) Antimicrobial effects of Quercus ilex L. extract. Phytother Res 18:208-211

Harris RN, James TY, Lauer A, Simon MA, Patel A (2006) Amphibian pathogen Batrachochytrium dendrobatidis is inhibited by the cutaneous bacteria of amphibian species. EcoHealth 3:53-56

Hossack BR, Adams MJ, Campbell Grant EH, Pearl CA and others (2010) Low prevalence of chytrid fungus (Batrachochytrium dendrobatidis) in amphibians of U.S. headwater streams. J Herpetol 44:253-260

- Hyatt AD, Boyle DG, Olsen V, Boyle DB and others (2007) Diagnostic assays and sampling protocols for the detection of Batrachochytrium dendrobatidis. Dis Aquat Org 73:175-192

Hyman OJ, Collins JP (2012) Evaluation of a filtration-based method for detecting Batrachochytrium dendrobatidis in natural bodies of water. Dis Aquat Org 97:185-195

Johnson PTJ, McKenzie VJ, Peterson AC, Kerby JL, Brown $\mathrm{J}$, Blaustein AR, Jackson T (2011) Regional decline of an iconic amphibian associated with elevation, land-use change, and invasive species. Conserv Biol 25:556-566

Karioti A, Sokovic M, Ciric A, Koukoulitsa C, Bilia AR, Skaltsa H (2011) Antimicrobial properties of Quercus ilex L. proanthocyanidin dimers and simple phenolics: evaluation of their synergistic activity with conventional antimicrobials and prediction of their pharmacokinetic profile. J Agric Food Chem 59:6412-6422

Kilburn VL, Ibáñez R, Green DM (2011) Reptiles as potential 
vectors and hosts of the amphibian pathogen Batrachochytrium dendrobatidis in Panama. Dis Aquat Org 97:127-134

Kilpatrick AM, Briggs CJ, Daszak P (2010) The ecology and impact of chytridiomycosis: an emerging disease of amphibians. Trends Ecol Evol 25:109-118

Konoshima T, Takasaki M (2002) Chemistry and bioactivity of the non-volatile constituents of eucalyptus. In: Coppen JJW (ed) Eucalyptus, the genus Eucalyptus. Taylor \& Francis, London, p 269-290

Kriger KM, Hero JM (2008) Altitudinal distribution of chytrid (Batrachochytrium dendrobatidis) infection in subtropical Australian frogs. Austral Ecol 33:1022-1032

Lane A, Burgin S (2008) Comparison of frog assemblages between urban and non-urban habitats in the upper Blue Mountains of Australia. Freshw Biol 53:2484-2493

> Longcore JE, Pessier AP, Nichols DK (1999) Batrachochytrium dendrobatidis gen. et sp. nov., a chytrid pathogenic to amphibians. Mycologia 91:219-227

Lötters S, Kielgast J, Bielby J, Schmidtlein S and others (2009) The link between rapid enigmatic amphibian decline and the globally emerging chytrid fungus. EcoHealth 6:358-372

Maerz JC, Brown CJ, Chapin CT, Blossy B (2005) Can secondary compounds of an invasive plant affect larval amphibians? Funct Ecol 19:970-975

McDonald K, Alford R (1999) A review of declining frogs in Northern Queensland. In: Campbell A (ed) Declines and disappearances of Australian frogs. Environment Australia, Canberra, p 14-22

> Murphy PJ, St-Hilaire S, Corn PS (2011) Temperature, hydric environment, and prior pathogen exposure alter the experimental severity of chytridiomycosis in boreal toads. Dis Aquat Org 95:31-42

Murray KA, Retallick RWR, McDonald KR, Mendez D and others (2010) The distribution and host range of the pandemic chytridiomycosis in Australia, spanning surveys from 1956-2007. Ecology 91:1557-1558

Murray KA, Retallick RWR, Puschendorf R, Skerratt LF and others (2011) Assessing spatial patterns of disease risk to biodiversity: implications for the management of the amphibian pathogen, Batrachochytrium dendrobatidis. J Appl Ecol 48:163-173

> Peterson JD, Wood MB, Hopkins WA, Unrine JM, Mendonça MT (2007) Prevalence of Batrachochytrium dendrobatidis in American bullfrog and southern leopard frog larvae from wetlands on the Savannah River site, South Carolina. J Wildl Dis 43:450-460

Puschendorf R, Hoskin CJ, Cashins SD, McDonald K, Skerratt LF, Vanderwal J, Alford RA (2011) Environmental refuge from disease-driven amphibian extinction. Conserv Biol 25:956-964

Raffel TR, Michel PJ, Sites EW, Rohr JR (2010) What drives chytrid infections in newt populations? Associations with substrate, temperature, and shade. EcoHealth 7:526-536

> Rohr JR, Halstead NT, Raffel TR (2011) Modelling the future distribution of the amphibian chytrid fungus: the influence of climate and human-associated factors. J Appl Ecol 48:174-176

Rollins-Smith LA, Conlon JM (2005) Antimicrobial peptide defenses against chytridiomycosis, an emerging infectious disease of amphibian populations. Dev Comp Immunol 29:589-598

Rollins-Smith LA, Carey C, Longcore JE, Doersam JK, Boutte A, Bruzgal JE, Conlon JM (2002) Activity of antimicrobial skin peptides from ranid frogs against Batrachochytrium dendrobatidis, the chytrid fungus associated with global amphibian declines. Dev Comp Immunol 26:471-479

Rollins-Smith LA, Ramsey JP, Pask JD, Reinert LK, Woodhams DC (2011) Amphibian immune defenses against chytridiomycosis: impacts of changing environments. Integr Comp Biol 51:552-562

Savage AE, Zamudio KR (2011) MHC genotypes associate with resistance to a frog-killing fungus. Proc Natl Acad Sci USA 108:16705-16710

Savage AE, Sredl MJ, Zamudio KR (2011) Disease dynamics vary spatially and temporally in a North American amphibian. Biol Conserv 144:1910-1915

Schlaepfer MA, Sredl MJ, Rosen PC, Ryan MJ (2007) High prevalence of Batrachochytrium dendrobatidis in wild populations of lowland leopard frogs Rana yavapaiensis in Arizona. EcoHealth 4:421-427

Schloegel LM, Ferreira CM, James TY, Hipolito M and others (2010) The North American bullfrog as a reservoir for the spread of Batrachochytrium dendrobatidis in Brazil. Anim Conserv 13:53-61

> Searle CL, Biga LM, Spatafora JW, Blaustein AR (2011) A dilution effect in the emerging amphibian pathogen Batrachochytrium dendrobatidis. Proc Natl Acad Sci USA 108:16322-16326

Shaw SD, Bishop PJ, Berger L, Skerratt LF and others (2010) Experimental infection of self-cured Leiopelma archeyi with the amphibian chytrid Batrachochytrium dendrobatidis. Dis Aquat Org 92:159-163

Sheafor B, Davidson EW, Parr L, Rollins-Smith LA (2008) Antimicrobial peptide defenses in the salamander, Ambystoma tigrinum, against emerging amphibian pathogens. J Wildl Dis 44:226-236

Skerratt LF, McDonald KR, Hines HB, Berger L and others (2010) Application of the survey protocol for chytridiomycosis to Queensland, Australia. Dis Aquat Org 92:117-129

Stice MJ, Briggs CJ (2010) Immunization is ineffective at preventing infection and mortality due to the amphibian chytrid fungus Batrachochytrium dendrobatidis. J Wildl Dis 46:70-77

Terzi V, Morcia C, Faccioli P, Valè G, Tacconi G, Malnati M (2007) In vitro antifungal activity of the tea tree (Melaleuca alternifolia) essential oil and its major components against plant pathogens. Lett Appl Microbiol 44: 613-618

Threlfall CG, Jolley DF, Evershed N, Goldingay RL, Buttemer WA (2008) Do green and golden bell frogs Litoria aurea occupy habitats with fungicidal properties? Aust Zool 34:350-360

- Van Sluys M, Hero JM (2009) How does chytrid infection vary among habitats? The case of Litoria wilcoxii (Anura, Hylidae) in SE Queensland, Australia. EcoHealth 6: 576-583

Woodhams DC, Alford RA (2005) Ecology of chytridiomycosis in rainforest stream frog assemblages of tropical Queensland. Conserv Biol 19:1449-1459

Woodhams DC, Rollins-Smith LA, Carey C, Reinert L, Tyler MJ, Alford RA (2006) Population trends associated with skin peptide defenses against chytridiomycosis in Australian frogs. Oecologia 146:531-540

- Woodhams DC, Geiger CC, Reinert LK, Rollins-Smith LA and others (2012) Treatment of amphibians infected with chytrid fungus: learning from failed trials with itraconazole, antimicrobial peptides, bacteria, and heat therapy. Dis Aquat Org 98:11-25 